\title{
Relationship Of Nutritional Components In Toddlers Aged 25-59 Months To Stunting And Short Stature Incidents In Pragaan District, Sumenep Regency

\author{
Pertiwi Febriana C. ${ }^{1}$, Conita Walida S. ${ }^{2}$
} \\ ${ }^{1}$ Medical Faculty and the Department of Pediatrician, University of Muhammadiyah
Malang, J1. Bendungan Sutami 188a Malang, East of Java, Indonesia
}

Email: pertiwi@umm.ac.id

Receive : Mart $2^{\text {th }}$ 2021. Revised : Apr $1^{\text {th }}$ 2021. Published: June $9^{\text {th }} 2021$

DOI : https://doi.org/10.22219/sm.Vol17.SMUMM1.15872

\begin{abstract}
Stunting and short stature are height per-age <-2SD for specific age and gender. The process of stunting and short stature starts from the womb until the beginning of life. The direct cause of stunting is the lack of nutritional intake in the first 1000 days of life, which can inhibit height growth. Study aimed to investigate the association between the relationship of nutritional components in toddlers to stunting and short stature incidents in Pragaan District, Sumenep Regency. Observational analytic with a case-control approach, using the Purposive-Sampling method. The research sample consisted of 76 toddlers aged 25-59 months. The statistical analysis used was the chi-square test and logistic regression test. The result of chi-square test and logistic regression for stunting on nutrient intake variable $(\mathrm{p}=0.000$, OR $=26,3$, CI 95\% $(4,630-153,573)$, history of breastfeeding $(\mathrm{p}=0,000, \mathrm{OR}=72,6, \mathrm{CI} 95 \%(7,63-690,78)$, iodized salt $(\mathrm{p}=0,000, \mathrm{OR}=8,5, \mathrm{CI} 95 \%$ $(1,833-39,421)$, FE tablet $(p=0,000, O R=37,00$, CI 95\%(3,762-363,91). The result of chi-square test and logistic regression for short stature on nutrient intake variable $(\mathrm{p}=0.001, \mathrm{OR}=7,2, \mathrm{CI} 95 \%(2,260-23,400)$, history of breast feeding $(\mathrm{p}=0,007, \mathrm{OR}=4,500, \mathrm{CI} 95 \%(1,210-16,742)$, iodized salt $(\mathrm{p}=0,007, \mathrm{OR}=19,125$, CI $95 \%(5,062-72,259)$, FE tablet $(\mathrm{p}=0,149)$. There is a relationship between nutritional components intakes such as breastfeeding history and iodine salt consumption with stunting and short stature in Pragaan District, Sumenep Regency.
\end{abstract}

Keywords : Nutrient, Short Stature, Stunting, Toddlers.

Copyright (C) 2021, Chandrawati et al This is an open access article under the CC-BY-SA license

\section{INTRODUCTION}

Stunting and short stature are height-for-age less than minus 2 standard deviations $(<-$ 2SD) for specific age and gender (Barstow, 2015). Stunting is part of short stature, but not all short stature is stunting. Stunting is associated with malnutrition and chronic infection, while short stature with low bone growth rate and other diseases causes growth failure (IDAI, 2017). Stunting will cause long-term effects in the form of diminished cognitive abilities and physical development, reduced productivity, poor health and an increased risk of degenerative diseases (WHO, 2014).The process of stunting starts from the time the child is in the womb until the early stages of life, namely the age of fewer than two years (WHO, 2014). 
In the 2015-2019 period, the government focused on health development programs, reducing stunting cases (Kemenkes RI, 2016). In 2016, Indonesia's stunting cases were 27.5\%, and in 2017, it increased to 29.6\% (Ministry of Health, 2018). The direct causes of stunting are lack of nutritional intake and infectious diseases (Trihono, 2015). Lack of nutritional intake from food will cause the use of body reserves, resulting in tissue deterioration which is marked by inhibition of height growth and weight loss (Harjatmo, 2017).

The Indonesian government joined the Scaling Up Nutrition (SUN) movement in 2012 by designing two broad stunting intervention frameworks. The frameworks carried out by the Indonesian government are specific nutrition interventions and sensitive nutrition interventions. Specific nutrition interventions are interventions dedicated to children within the first 1000 days of life $(\mathrm{HPK})$ and contribute to a 30\% reduction in stunting. Specific nutritional interventions start from maternal pregnancy to childbirth. Specific nutrition interventions targeted pregnant women, breastfeeding mothers for children aged 0-6 months and mothers breastfeeding children aged 7-23 months (TNP2K, 2017). Specific nutrition interventions by promoting optimal nutritional practices. First, increasing the nutritional intake of pregnant women by giving iron, folic acid, and iodine supplements isessential for developing the child's nervous system (Sarah, 2018). Second, early initiation of breastfeeding (IMD) one hour after birth. Third, exclusive breastfeeding for children aged 0-6 months is continued until they are two years old. Fourth, complementary feeding after six months of age, provision of vitamin A capsules and use of iodized salt in food (Unicef, 2013)

Data from the National Team for the Acceleration of Poverty Reduction (TNP2K) shows that Sumenep Regency is one of the 100 priority districts or cities for stunting Indonesia's intervention. The prevalence of stunting in Sumenep Regency is 52.44\%, around 33,196 children out of 1076 thousand people. Sumenep Regency has 27 sub-districts, one of which is Praga District (TNP2K, 2017).

Based on the description above, the authors are interested in writing about the Relationship of Nutritional Components Intake of Toddlers Age 25-59 Months and Stunting and Short Stature cases in Praga District Sumenep Regency.

\section{METHODS}

This research is an observational study using the case-control method, using primary data through questionnaires and interviews with mothers, taking anthropometric measurements and DDST. This research was conducted for 2 weeks in PragaDistrict, Sumenep Regency. The sampling technique was purposive sampling. This study's samples were toddlers aged 25-59 months in PragaDistrict, Sumenep Regency who met the inclusion criteria, namely children aged 25-59 months with TB / U <-2SD for cases and toddlers aged 25-59 months $>$-2SD for control. The total sample in this study were 76 respondents. This study's independent variable was nutritional 
intake, and the dependent variable in this study was stunting and short stature. This study's instruments were a height measuring device, a digital weight measuring device, Denver II, and a nutritional intake questionnaire. The data analysis used was the chi-square test and regression test.

\section{RESULTS AND DISCUSSION}

After researching the relationship of nutritional intake to children aged 25-59 months to the incidence of stunting and short stature in Praga District, Sumenep Regency, 76 respondents consisted of 38 under-five who experienced stunting and short stature as cases and 38 normal toddlers as controls.

Table 1. Distribution of Sample Characteristics

\begin{tabular}{llcc}
\hline \multicolumn{1}{c}{ Characteristics } & \multicolumn{1}{c}{ Category } & Frequency & Percentage $(\%)$ \\
\hline Toddler Age & $25-36$ months & 39 & $52,2 \%$ \\
& $37-48$ months & 20 & $26,3 \%$ \\
& $49-59$ months & 17 & $21,0 \%$ \\
Gender & Total & 76 & $100 \%$ \\
& Male & 36 & $47,3 \%$ \\
\multirow{3}{*}{ Mother's last education } & Female & 40 & $52,7 \%$ \\
& Total & 76 & $100 \%$ \\
& Elementary & 17 & $22,4 \%$ \\
& school & & $32,9 \%$ \\
& Juniorhigh & 25 & $34,2 \%$ \\
& school & & $6,6 \%$ \\
& High school & 26 & $3,9 \%$ \\
& Diploma & 5 & $100 \%$ \\
\hline
\end{tabular}

Table 1 shows that the most under-fives are 25-59 months with 39 under-fives (52.5\%), the highest gender is female as much as 40 toddlers (53.9\%), and the most recent education for mothers is SMA as many as 26 toddlers $(34,2 \%)$. 
Table 2. Frequency Distribution Based on Stunting, Short Stature and Normal Incidents by

Gender

\begin{tabular}{lcccccc}
\hline \multicolumn{1}{c}{ Characteristics } & \multicolumn{2}{c}{ Male } & \multicolumn{2}{c}{ Female } & \multicolumn{2}{c}{ Total } \\
\hline & $\mathrm{N}$ & $\%$ & $\mathrm{~N}$ & $\%$ & $\mathrm{~N}$ & $\%$ \\
\hline Stunting & 7 & $9,2 \%$ & 5 & $6,6 \%$ & 12 & $15,8 \%$ \\
Short stature & 15 & $19,8 \%$ & 11 & $14,5 \%$ & 26 & $34,2 \%$ \\
Normal & 17 & $22,4 \%$ & 21 & $27,6 \%$ & 38 & $50 \%$ \\
Total & 39 & $51,4 \%$ & 37 & $48,6 \%$ & 76 & $100 \%$ \\
\hline
\end{tabular}

Table 2 shows that respondents who experienced stunting were 12 toddlers (15.8\%), consisting of 7 boys (58.3\%) and 5 girls (41.7\%). 26 toddlers experienced short stature (34.2\%), consisting of 15 boys (57.7\%) and 11 girls (42.3\%). Normal toddlers as many as 38 toddlers (50\%) consisting of 17 boys $(44.7 \%)$ and 21 toddler girls (55.3\%).

Table 3. Frequency Distribution Based on Stunting, Short Stature and Normal Incidence by Age

\begin{tabular}{lcccccccc}
\hline \multicolumn{1}{c}{ Characteristics } & \multicolumn{2}{c}{$25-36$ months } & \multicolumn{2}{c}{$37-48$ months } & \multicolumn{2}{c}{$49-59$ months } & \multicolumn{2}{c}{ Total } \\
\hline Stunting & $\mathrm{N}$ & $\%$ & $\mathrm{~N}$ & $\%$ & $\mathrm{~N}$ & $\%$ & $\mathrm{~N}$ & $\%$ \\
Short stature & 7 & $9,2 \%$ & 1 & $1,3 \%$ & 4 & $5,3 \%$ & 12 & $15,8 \%$ \\
Normal & 11 & $14,5 \%$ & 9 & $11,8 \%$ & 6 & $7,9 \%$ & 26 & $34,2 \%$ \\
Total & 21 & $27,6 \%$ & 7 & $9,2 \%$ & 10 & $13,2 \%$ & 38 & $50 \%$ \\
\hline
\end{tabular}

Table 3 shows that respondents who experienced stunting were 12 infants (15.8\%), with the highest prevalence at the age of 25-36 months. 26 toddlers experienced short stature (34.2\%), with the highest prevalence aged 25-36 months.

Table 4 Multivariate Analysis of Logistic Regression of Nutritional Intake of Stunting

\begin{tabular}{|c|c|c|c|c|c|c|c|}
\hline \multicolumn{2}{|c|}{ Variable } & \multirow[b]{2}{*}{ Stunting } & \multirow[b]{2}{*}{ Normal } & \multirow{2}{*}{$\mathrm{P}$} & \multirow{2}{*}{ OR } & \multicolumn{2}{|c|}{ CI } \\
\hline & & & & & & Lower & Upper \\
\hline \multirow{2}{*}{$\begin{array}{l}\text { Nutritional } \\
\text { intake }\end{array}$} & Good & $2(8,2 \%)$ & $32(25,8 \%)$ & \multirow[b]{2}{*}{0,000} & \multirow[b]{2}{*}{0,038} & \multirow[b]{2}{*}{0,007} & \multirow[b]{2}{*}{0,216} \\
\hline & $\begin{array}{c}\text { Deficie } \\
\text { nt }\end{array}$ & $10(3,8 \%)$ & $6(12,2 \%)$ & & & & \\
\hline \multirow{2}{*}{$\begin{array}{c}\text { History of } \\
\text { Breastfeeding }\end{array}$} & Good & $1(1,3 \%)$ & $33(43,4 \%)$ & \multirow{2}{*}{0,000} & \multirow{2}{*}{72,600} & \multirow{2}{*}{7,630} & \multirow{2}{*}{$\begin{array}{c}690,78 \\
3\end{array}$} \\
\hline & Bad & $11(14,5 \%)$ & $5(6,6 \%)$ & & & & \\
\hline \multirow[t]{2}{*}{ Iodized Salt } & Yes & $6(7,9 \%)$ & $34(44,7 \%)$ & \multirow[b]{2}{*}{0,000} & \multirow[b]{2}{*}{8,500} & \multirow[b]{2}{*}{1,833} & \multirow[b]{2}{*}{39,421} \\
\hline & No & $6(7,9 \%)$ & $4(5,3 \%)$ & & & & \\
\hline Iron & Yes & $6(7,9 \%)$ & $37(48,7 \%)$ & 0,000 & 37,000 & 3,762 & 363,91 \\
\hline
\end{tabular}




$\begin{array}{llll}\text { Supplements } & \text { No } & 6(7,9 \%) & 1(1,3 \%)\end{array}$

Table 4 shows that the multivariate analysis results showed that the variables of nutritional intake, history of breastfeeding, iodized salt, and iron supplements had a significant relationship ( $p$ $<0.05)$. This study found a positive relationship with stunting in the variable nutritional intake, history of breastfeeding, use of iodized salt in the family, and iron supplements by mothers during pregnancy.

Table 5 Multivariate Analysis of Logistic Regression of Nutrition Intake of Short Stature

\begin{tabular}{|c|c|c|c|c|c|c|c|}
\hline & \multirow[b]{2}{*}{$\begin{array}{l}\text { Short } \\
\text { Stature }\end{array}$} & \multirow[b]{2}{*}{ Normal } & \multirow{2}{*}{$\mathrm{P}$} & \multirow{2}{*}{ OR } & \multicolumn{2}{|c|}{ CI } \\
\hline Varial & & & & & & Lower & Upper \\
\hline \multirow{2}{*}{$\begin{array}{l}\text { Nutritional } \\
\text { intake }\end{array}$} & Good & $11(17,5 \%)$ & $32(25,8 \%)$ & \multirow[b]{2}{*}{0,001} & \multirow[b]{2}{*}{0,138} & \multirow[b]{2}{*}{0,043} & \multirow[b]{2}{*}{0,442} \\
\hline & Deficient & $15(8,5 \%)$ & $6(12,2 \%)$ & & & & \\
\hline $\begin{array}{c}\text { History of } \\
\text { Breastfeeding }\end{array}$ & Good & $17(22,4 \%)$ & $33(43,4 \%)$ & \multirow{2}{*}{0,007} & \multirow{2}{*}{4,500} & \multirow{2}{*}{1,210} & \multirow[b]{2}{*}{16,742} \\
\hline & $\mathrm{Bad}$ & $9(11,8 \%)$ & $5(6,6 \%)$ & & & & \\
\hline \multirow[t]{2}{*}{ Iodized Salt } & Yes & $8(10,5 \%)$ & $34(44,7 \%)$ & \multirow[b]{2}{*}{0,007} & \multirow[b]{2}{*}{19,125} & \multirow[b]{2}{*}{5,062} & \multirow[b]{2}{*}{72,259} \\
\hline & No & $18(23,7 \%)$ & $4(5,3 \%)$ & & & & \\
\hline \multirow{2}{*}{$\begin{array}{c}\text { Iron } \\
\text { Supplements }\end{array}$} & Yes & $22(28,9 \%)$ & $37(48,7 \%)$ & \multirow[b]{2}{*}{0,149} & \multirow{2}{*}{6,727} & \multirow[b]{2}{*}{0,706} & \multirow[b]{2}{*}{64,079} \\
\hline & No & $4(5,3 \%)$ & $1(1,3 \%)$ & & & & \\
\hline
\end{tabular}

Table 5 displays that the multivariate analysis results showed that the variable nutritional intake, history of breastfeeding, and iodized salt had a significant relationship $(\mathrm{p}<0.05)$, while iron supplements showed insignificant results. This study found a positive relationship with short stature in the variable nutritional intake, history of breastfeeding, use of iodized salt in the family, and iron supplements by mothers during pregnancy.

\section{DISCUSSION}

Characteristics based on gender

The study results were 76 research data consisting of 36 male children under five and 40 female children. As many as 7 male children under five were stunted, 15 had short stature, and the remaining 17 were normal. " Toddlers who are female consist of 5 children stunted, 11 children have short stature, and 24 children are normal. It can be concluded that male toddlers experience stunting and short stature more than girls. This result is in accordance with Mugianti's research 
(2018) in Sukorejo and Setyawati Subdistricts (2018) in Semarang City that the prevalence of stunting and short stature of male toddlers is higher than female toddlers because male toddlers develop faster and more diverse motor skills, so they require more energy than girls, so if the nutritional intake is not fulfilled, it will cause stunting and short stature. Another research conducted by Akombi (2017) states that the cause of this is the occurrence of gender inequality in the prevailing local community or culture by giving special treatment to female toddlers who tend to stay at home, while male toddlers are more physically active.

Characteristics by age

The results showed that from 76 research data, there were 39 children aged 25-36 months, 20 children aged 37-48 months and 17 children 49-59 months. There were 7 children aged 25-36 months who were stunted, 11 children had short stature, and 21 children were normal, bringing 39 children. For children aged 37-48 months, 1 child was stunted, 9 children had short stature and 7 normal children. For toddlers aged 49-59 months, 4 children are stunted, 6 children have short stature, and 10 children are normal. These results show that the highest stunting incidence and short stature is in infants aged 25-36 months.

Riskesdas 2018 states that in 2018, Indonesia's prevalence mostly occurs in children aged 23 years with a percentage of $41.4 \%$ of the total population of stunting children in Indonesia (Trihono, 2015). Child growth will be optimal in the first two years of life, and the incidence of stunting is a chronic impact that appears due to the lack of nutritional intake at the age of under 25 months (Desyanti, 2017). This research is in line with Setyawati's research (2018) which states that entering the age of 24 months, the child begins to enter the weaning phase and a period of high activity in exploring the surrounding environment. Gross motor skills in toddlers also grow and develop rapidly. At this stage, some toddlers will face several possibilities that cause nutritional deficiencies such as decreased appetite, poor nutritional intake, reduced sleep hours and are prone to infection when mothers or caregivers pay less attention to hygiene and sanitation so that at this age, the child needs more attention in terms of nutritional intake due to higher energy requirements and more varied dietary needs compared to children aged 0-2 years.

Characteristics based on the mother's education level

The results showed that the most recent education for mothers was SMA. According to Anisa (2012), the low level of maternal education affects the incidence of stunting. According to Mugianti (2018), mothers who are well educated will have good nutritional knowledge, especially in terms of processing food, managing food menus and maintaining good food quality and hygiene. According to Heile (2016), parents who are highly educated will more easily receive education about health, especially about pregnancy and the importance of nutritional intake for toddlers and the importance of exclusive breastfeeding. Nutritional intake can cause stunting and short stature. 
The results showed that most of the samples that were stunted had insufficient nutritional intake. Chi-square test results showed significant results if the p-value was $<0.005$. It can be seen that toddlers who have less nutritional intake are at higher risk of stunting than toddlers with good nutritional intake and statistically significant results. There are 10 toddlers with low nutritional intake and stunting, most of whom consume $<6$ types of food a day. Toddlers with good nutritional intake consumed $\geq 6$ types of food during the last 24 hours. The food consumed by children under five is less diverse. Most of them consume eggs, fish, tofu, tempeh, oil and Moringa leaves. Children rarely consume meat such as chicken and beef. The low economic status in the family also has an important role, so that it affects the purchasing power of the community for this type of food.

Nurmayasanti (2017) states that stunted children have insufficient nutritional intake and lack of milk, poultry, and beef consumption. Therefore, it is necessary to promote health about the intake consumed during pregnancy until the child is two years old. Meat from animals can increase iron intake, an essential micronutrient essential for reducing anemia and growth. Iron deficiency is also associated with stunted development (Caufield, 2006). This study's results are in line with Riyadi et al. (2006), which states that the types and amounts of food consumed by the normal group of children are more diverse compared to the stunting and short stature groups. It is essential to provide adequate nutritional intake for children because it can affect normal growth patterns to be caught up (Rahayu, 2011).

The study results also showed that toddlers who were stunted and of short stature had good nutritional intake. Stunting and short stature are related to the growth and development of children under five. Two factors affect children's growth under five apart from nutritional intake, namely genetic factors and environmental factors. Genetic factors are inherited traits passed on by parents so that toddlers with short parents are likely to have less than optimal height even with a good nutritional intake (Harjatmo, 2017).

Environmental factors that influence growth are the prenatal and postnatal environment. The prenatal environment is the mother's nutritional status during pregnancy, so there is a risk of giving birth to a baby with LBW, which will inhibit growth and inhibit the development of fetal brain cells in the womb. The postnatal environment is influenced by gender, age, race or ethnicity and growth hormone (Harjatmo, 2017).

Judging from the pattern of the mother's behaviour seen through the history of breastfeeding, this study found that most of the subjects in the case group did not receive exclusive breastfeeding for 6 months. Feeding other than breastfeeding is too early, namely before the age of 6 months, food such as instant porridge is given, and some are given formula milk from the age of one week. Most of the control group received exclusive breastfeeding for 6 months and were only given complementary foods after 6 months. This study is in accordance with the research of 
Meilyasari (2014), which states that children who do not receive exclusive breastfeeding are at risk of stunting because breast milk contains antibodies that can prevent children from developing infections so that feeding too early will make children susceptible to infectious diseases such as diarrhoea and ISPA. The results of interviews with mothers of toddlers found that children who were given instant porridge and formula milk at an early age were because the child was fussy if they were not given food other than breast milk; besides that, it was also caused by breast milk that was not smooth.

Lestari's research (2018) states that non-exclusive breastfeeding for toddlers is associated with stunting and is five times riskier than toddlers who are exclusively breastfed. Padmadas' study (2002) states that giving foods other than breast milk at a too early age at 0-2 months of age has the risk of causing stunting at 2-4 years of age. This study is also in line with research conducted by Nadia (2018), which states that there is a significant relationship between exclusive breastfeeding and stunting. This study contradicts the study of Anisa (2012), which states that there is no relationship between exclusive breastfeeding and stunting and short stature.

The results showed a significant relationship between children under five who experienced stunting and short stature in Praga District, Sumenep Regency, with the use of iodized salt. Toddlers who experience stunting and short stature do not consume iodized salt more than normal toddlers. In line with Simbolon's research (2018), low iodine consumption is associated with growth disorders. According to Caulfield (2006), iodine deficiency will impact intellectual development and physical growth. Low iodine consumption will cause the thyroid gland to be unable to secrete thyroid hormones so that it can interfere with metabolic processes, growth and tissue development, especially the nervous system and brain (Ministry of Health, 2017).

The results showed a significant relationship between the incidence of stunting and consumption of iron supplements during pregnancy, and there is no significant relationship between the incidence of short stature with iron supplements during pregnancy. The deficiency of micronutrients during pregnancy, such as iron, is associated with fetal growth and LBW. The micronutrient deficiency is due to not consuming iron supplements during pregnancy, but it is also caused by a lack of meat-containing heme iron consumption. Iron supplements have a significant effect on LBW. In Nepal, pregnant women who do not take iron supplements are more likely to have LBW babies (Vir, 2016). Ernawati et al.'s study found that 9.5\% of babies with LBW and $22 \%$ of them were stunted.

The final result of this study was obtained that toddlers with less nutritional intake will be at risk of 26 times stunting compared to toddlers who get good nutritional intake. Toddlers who are not given exclusive breast milk will be at risk of 72 times the occurrence of stunting compared to toddlers who are breastfed exclusively. Foods that do not contain iodized salt are at 8.5 times more risk of stunting than when the toddler consumes foods with the addition of iodized salt. The 
absence of micronutrients in the form of iron supplements in pregnant women will be at risk 37 times the baby born later will be stunting compared to mothers who are given iron supplementation while pregnant.

Toddlers with less nutritional intake will be at risk of 7.2 times being short stature compared to toddlers who get a good nutritional intake. Toddlers who are not given exclusive breast milk will be at risk of 4.5 times the occurrence of short stature compared to toddlers who are breastfed exclusively. Foods that do not contain iodized salt are at risk of 19 times short stature compared to when the toddler consumes foods with the addition of iodized salt. The absence of micronutrients in the form of iron supplements in pregnant women had no effect on the case of short stature in toddlers studied in this study.

Study Limitations

This study has several limitations: this study does not discuss the development of brain cells of toddlers who are stunted, short stature, and normal toddlers. This study also did not discuss mothers' nutritional status during pregnancy, which could be seen through LILA. Still, many of the respondents did not remember the size of LILA during pregnancy.

\section{CONCLUSION}

From this study obtained factors that affect the incidence of stunting in toddlers are: insufficient nutritional intake, non-exclusive breastfeeding, foods that do not contain iodized salt and not given iron supplements in pregnant women. While the factors that affect toddlers with short stature are: lack of nutrition intake, non-exclusive breastfeeding, and foods that do not contain iodized salt.

\section{RECOMMENDATIONS}

Future researchers are expected to conduct further research on the relationship of nutritional intake in children aged 25-59 months with stunting and short stature. Further researchers are also expected to research how the development of brain cells in toddlers who are stunted, short stature and normal toddlers, and research how the history of maternal nutritional status during pregnancy is related to toddlers who experience stunting and short stature.

\section{REFERENCES}

A. K. Yousafzai et al., "Effects of responsive stimulation and nutrition interventions on cbildren"s development and growth at age 4 years in a disadvantaged population in Pakistan: a longitudinal follow-up of a 
cluster-randomised factorial effectiveness trial,” The Lancet Global Health, vol. 4, no. 8, pp. e548-e558, 2016.

A. Samuel et al., "Effectiveness of a program intervention with reduced-iron multiple micronutrient powders on iron status, morbidity and growth in young children in Ethiopia," Nutrients, vol. 10, no. 10, 2018.

Abeway, S., Gebremichael, B., Murugan, R., Assefa, M., \& Adinew, Y. M. (2018). Stunting and its determinants among children aged 6-59 months in Northern Ethiopia: A cross-sectional study. Journal of Nutrition and Metabolism, 2018, 1078480. doi: 10.1155/2018/1078480

Aguayo VM, Nair R, Badgaiyan N, Krishna V. Determinants of stunting and poor linear growth in children under 2 years of age in India: An in-depth analysis of Maharashtra's comprehensive nutrition survey. Matern Child Nutr. 2016;12:121-40.

Akombi, B. J. et al. Stunting and severe stunting among children under-5 years in Nigeria: A multilevel analysis. BMC Pediatr. 17, 1-17 (2017).

Akombi, Blessing Jaka. Agho Kingsley E, Hall John J, MeromDafna, Astel- Burt Thomas, and Renzaho Andre M.N. (2017). Stunting and severe stunting among children under-5 years in Nigeria: A multilevel analysis. Nigeria: BMC Pediatrics

Aryastami, N. K. et al. Low birth weight was the most dominant predictor associated with stunting among children aged 12-23 months in Indonesia. BMC Nutr. 3, 16 (2017).

Aryastami NK, Tarigan I. Kajian Kebijakan dan Penanggulangan Masalah Gizi Stunting di Indonesia. Bul Penelit Kesehat [Internet]. 2017;45(4):233-40. Available from: http:/ / ejournal.litbang.depkes.go.id/index.php/BPK/article/download/7465/5434

Atsu BK, Guure C, Laar AK. Determinants of overweight with concurrent stunting among Ghanaian children. BMC Pediatr. 2017;17(1):1-12.

Ban, L., Guo, S., Scherpbier, R. W., Wang, X., Zhou, H., \& Tata, L. J. (2017). Child feeding and stunting prevalence in left-behind children: a descriptive analysis of data from a central and western Chinese population. International Journal of Public Health, 62(1), 143-151. doi: $10.1007 /$ s00038-016-0844-6

Batiro, B., Demissie, T., Halala, Y., \& Anjulo, A. A. (2017). Determinants of stunting among children aged 6-59 months at Kindo Didaye woreda, Wolaita Zone, Southern Ethiopia: Unmatched case control study. PloS One, 12(12), e0189106. doi: $10.1371 /$ journal.pone.0189106

Beal T, Tumilowicz A, Sutrisna A, Izwardy D, Neufeld LM. A review of child stunting determinants in Indonesia. Matern Child Nutr. 2018;14(4):1-10.

Berhanu, G., Mekonnen, S. \& Sisay, M. Prevalence of stunting and associated factors among preschool children: A community based comparative cross sectional study in Ethiopia. BMC Nutr. 4, 28 (2018).

Bogale, T. Y., Bala, E. T., Tadesse, M. \& Asamoah, B. O. Prevalence and associated factors for stunting among 6-12 years old school age children from rural community of Humbo 
district, Southern Ethiopia. BMC Public Health 1-9 (2018). doi:10.1186/s12889-018$5561-z$

Candra, A. Suplementasi mikronutrien dan penanggulangan malnutrisi pada anak usia di bawah lima tahun (balita). Jnh 5, 8 (2017).

D. Tosheno, Y. M. Adinew, T. Thangavel, and S. B. Workie, "Risk factors of underweight in children aged 6-59 months in Ethiopia," Journal of Nutrition and Metabolism, vol. 2017, Article ID 6368746, 8 pages, 2017.View at: $\underline{\text { Publisher Site | Google Scholar }}$

Das, J.K.; Salam, R.A.; Hadi, Y.B.; Sadiq Sheikh, S.; Bhutta, A.Z.; Weise Prinzo, Z.; Bhutta, Z.A. Preventive lipid-based nutrient supplements given with complementary foods to infants and young children 6 to 23 months of age for health, nutrition, and developmental outcomes. Cochrane Database

De-Regil, L.M.; Jefferds, M.E.D.; Pena-Rosas, J.P. Point-of-use fortification of foods with micronutrient powders containing iron in children of preschool and school-age. Cochrane Database Syst. Rev. 2017, 11, CD009666. [Google Scholar] [CrossRef] [ubMed]

Desyanti, \&Nindya. (2017). Hubungan Riwayat PenyakitDiare dan PraktikHigienedenganKejadianStunting pada BalitaUsia 24-59 Bulan di Wilayah KerjaPuskesmasSimolawang, Surabaya. Research Study, 248.Syst. Rev. 2019, 5, CD012611. [ $\underline{\text { Google Scholar] [CrossRef] [PubMed) }}$

E. K. B. Desalegn, K. Fikre, and T. Bosha, "Stunting and its associated factors in under five years old children: the case of Hawassa University Technology villages, Southern Ethiopia," Journal of Environmental Science, Toxicology and Food Technology, vol. 10, no. 11, pp. 25-31, 2016.View at: Google Scholar

Ek, A., Sorjonen, K., Eli, K., Lindberg, L., Nyman, J., Marcus, C., \& Nowicka, P. (2016). Associations between parental concerns about preschoolers' weight and eating and parental feeding practices: Results from analyses of the child eating habit questionnaire, the child feeding questionnaire, and the lifestyle behavior checklist. PLoS One, 11(1), 120. doi: $\underline{10.1371 / \text { journal.pone. } 0147257}$

E. Reifsnider, C. N. Shin, M. Todd, M. Jeong, M. Gallagher, and M. Moramarco, "How Did They Grow: An Intervention to Reduce Stunted Growth in Low-Income Mexican-American Children," Research in Nursing and Health, vol. 39, no. 2, pp. 105-120, 2016.

Geberselassie, S. B., Abebe, S. M., Melsew, Y. A., Mutuku, S. M. \& Wassie, M. M. Prevalence of stunting and its associated factors among children 6-59 months of age in Libo-Kemekem district, Northwest Ethiopia; A community based cross sectional study. PLoS One 13,112 (2018).

Haile, Demwoz, AzageMmuluken, Mola Togegn and Rainey Rochelle. (, 2016). Exploring Spatial Variations and Factors Associated with Childhood Stunting in Ethiopia: Spatial and Multilevel Analysis. Ethiopia:BMC Pediatrics 
Harjatmo, T. P. (2017). Penilaian Status Giz̨i. Jakarta: Pusat Pendidikan SumberDayaManusia Kesehatan.

Himaz, R. (2018). Stunting later in childhood and outcomes as a young adult: Evidence from India. World Development, 104, 344-357. doi: 10.1016/j.worlddev.2017.12.019

Hwalla N, Al Dhaheri AS, Radwan H, Alfawaz HA, Fouda MA, Al-Daghri NM, et al. The prevalence of micronutrient deficiencies and inadequacies in the middle east and approaches to interventions. Nutrients. 2017;9(3):1-29.

IDAI . (2017). PerawakanPendek pada Anak dan Remaja di Indonesia.Jakarta : Badan PenerbitIkatanDokter Anak Indonesia.

Illahi RK. Hubungan Pendapatan Keluarga, Berat Lahir, Dan Panjang Lahir Dengan Kejadian Stunting Balita 24-59 Bulan Di Bangkalan. J Manaj Kesehat Yayasan RSDr Soetomo [Internet]. 2017;3(1):1-7. Available from: $\underline{\text { http://jurnal.stikes- }}$ yrsds.ac.id/index.php/JMK/article/view/85/83

J. L. Roberts and A. D. Stein, "The Impact of Nutritional Interventions beyond the First 2 Years of Life on Linear Growth: A Systematic Review and Meta-Analysis.," Advances in nutrition (Bethesda, Md.), vol. 8, no. 2, pp. 323-336, Mar. 2017.

Keats EC, Imdad A, Das JK, Bhutta ZA. Protocol : Efficacy and effectiveness of micronutrient supplementation and fortification interventions on the health and nutritional status of children under-five in low and middle-income countries : a systematic review. 2018;(August).

KEMENKES. (2018). Cegah Stunting denganPerbaikan Pola Makan, Pola Asuh dan Sanitasi. Jakarta: Biro Kementerian Kesehatan RI.

KEMENKES. (2016). Laporan Hasil Riset Kesehatan Dasar (Riskesdas). SituasiBalitaPendek, 1.

Kemenkes RI. (2017). BukuSakuPemantanan Status Gizi. Jakarta: DirektoratGizi Masyarakat.

Kemenkes RI. (2016). SituasiBalitaPendek. Jakarta Selatan: Pusat Data dan Informasi.

Kismul, H., Acharya, P., Mapatano, M. A., \& Hatløy, A. (2017). Determinants of childhood stunting in the Democratic Republic of Congo: Further analysis of Demographic and Health Survey 2013-14. BMC Public Health, 18(1), 1-15. doi: 10.1186/s12889-017-4621-0

Koini, S. M., Ochola, S., \& Oggada, I. A. (2019). Social-cultural factors and complementary feeding of children 6-23 months among the Maasai in Narok South Kenya. Journal of Health, 62, 170-177. doi: $10.7176 / \mathrm{JHMN}$

Lestari, Dewi. (, 2018). Correlation Between Non-Exclusive Breastfeeding and Low Birth Weight to Stunting In Children. http://dx.doi.org/10.14238/pi58.3.2.2018.123.7

Minist Aryastami NK, Shankar A, Kusumawardani N, Besral B, Jahari AB, Achadi E. Low birth weight was the most dominant predictor associated with stunting among children aged 12-23 months in Indonesia. BMC Nutr [Internet]. 2017;3(1):16. Available from:http://bmcnutr.biomedcentral.com/articles/10.1186/s40795-017-0130-x 
Ministry of Health Republic of Indonesia [MoHRI]. (2018). Pusat data dan informasi: Situasi balita pendek (Stunting) di Indonesia [Data and information center: Short toddler situation (Stunting) in Indonesia]. Buletin Jendela Data dan Informasi. Jakarta: Kementerian Kesehatan RI

N. Zhang, L. Bécares, T. Chandola. Patterns and determinants of double-burden of malnutrition among rural children: evidence from China. PLOS ONE, 11 (2016), pp. 120http://dx.doi.org/10.1371/journal.pone.0158119

Nshimyiryo, A. et al. Risk factors for stunting among children under five years : a cross-sectional population-based study in Rwanda using the 2015 Demographic and Health Survey. 1-10 (2019).

Nurmayasanti, Atin.(2019). Status SosialEkonomi dan KeberagamanPangan Pada Balita Stunting dan Non StuntingUsia 24-59 Bulan di Wilayah KrjaPuskesmasWilanganKabupatenNganjuk.

Pang, W. W., Tan, P. T., Cai, S., Fok, D., Chua, M. C., Lim, S. B., ... \& Gluckman, P. D. (2019). Nutrients or nursing? Understanding how breast milk feeding affects child cognition. European Journal of Nutrition, 59(2), 609-619. doi: 10.1007/s00394-019-01929-2

Paramashanti BA, Hadi H, Gunawan IMA. Pemberian ASI eksklusif tidak berhubungan dengan stunting pada anak usia 6-23 bulan di Indonesia. J Gizi dan Diet Indones (Indonesian J Nutr Diet [Internet]. 2016;3(3):162. Available from:http://ejournal.almaata.ac.id/index.php/IJND/article/view/312

Pertiwi D, Kusudaryati D, Muis SF, Widajanti L. Pengaruh suplementasi Zn terhadap perubahan indeks TB / U anak stunted usia 24-36 bulan. J Gizi Indones. 2017;5(2):98-104.

Pokhrel, K., Nanishi, K., Poudel, K. C., Pokhrel, K. G., Tiwari, K., \& Jimba, M. (2016). Undernutrition among children aged 12-59 months and children in Nepal: maternal health services and their roles to prevent it. Maternal and Child Health Journal, 20(10), 2037-2049. doi: 10.1007/s10995-016-2023-Z

Public Health Office of Bangka Belitung Islands Province (2017). Profil kesehatan Provinsi Kepulauan Bangka Belitung [Health profile of the Bangka Belitung Islands Province]. Pangkalpinang: Dinas Kesehatan Provinsi Kepulauan Bangka Belitung

Rahman, N., Napirah, M. R., Nadila, D., \& Bohari. (2017). Determinants of stunting among children in urban families in Palu, Indonesia. Pakistan Journal of Nutrition, 16(10), 750756. doi: $\underline{10.3923 / \mathrm{pjn} .2017 .750 .756}$

Rachmi CN, Agho KE, Li M, Baur LA. Stunting, underweight and overweight in children aged 2.04.9 years in Indonesia: Prevalence trends and associated risk factors. PLoS One [Internet]. 2016;11(5):1-18. Available from: http://dx.doi.org/10.1371/journal.pone.0154756

S. Hagos, D. Hailemariam, T. WoldeHanna, B. Lindtjørn.Spatial heterogeneity and risk factors for stunting among children under age five in Ethiopia: a Bayesian geo-statistical model.

PLOS ONE, 12 (2017), pp. 1-19http://dx.doi.org/10.1371/journal.pone.0170785 
Saavedra, J. M., \& Dattilo, A. M. (2016). Nutrition in the first 1000 days of life: Society's greatest opportunity. Early nutrition and long-term health: Mechanisms, consequences, and opportunities. Oxford: Elsevier

Sarah, S. (2018). Advocacy for Improving Nutrition in The First 1000 Days to Support Childhood Development and Adult Health. American Academy of Pediatrics, 3.

Setiawan, E., Machmud, R., \& Masrul, M. (2018). Faktor-faktor yang berhubungan dengan kejadian stunting pada anak usia 24-59 bulan di wilayah Kerja Puskesmas Andalas Kecamatan Padang Timur Kota Padang tahun 2018 [Factors related to the incidence of stunting in children aged 24-59 months in the working area of Andalas Public Health Center, Padang Timur District, Padang City in 2018]. Jurnal Kesehatan Andalas, 7(2), 275-284

TNP2K. (2017). 100 Kabupaten/Kota PrioritasUntukIntervensi Anak Kerdil (Sunting ). Sekretariat Wakil PresidenRepublikIndonesia, 5.

Torlesse H, Cronin AA, Sebayang SK, Nandy R. Determinants of stunting in Indonesian children: Evidence from a cross-sectional survey indicate a prominent role for the water, sanitation and hygiene sector in stunting reduction. BMC Public Health [Internet]. 2016;16(1):1-11. Available from: http://dx.doi.org/10.1186/s12889-016-3339-8

United Nations Children's Fund, the World Health Organization and World Bank Group (2017). Level and Trends in Child Malnutrition: UNICEF/WHO/World Bank Group Joint Child Malnutrition Estimates. Washington DC: United Nations Children's Fund, the World Health Organization and World Bank Group

United Nations Children's Fund. (2017). First 1000 days: The critical window to ensure that children survive and thrive. South Africa: United Nations Children's Fund

Vir, Sheila.(, 2016). Improving Women's Nutrition Imperative for Rapid Reduction of Childhood Stunting In South Asia: Coupling of Nutrition Specific Interventions with Nutrition-Sensitive Measures Essential. Public Health Nutrition and Development Centre. New Delhi.

Wellina WF, Kartasurya MI, Rahfilludin MZ. Faktor risiko stunting pada anak umur 12-24 bulan. J Gizi Indones. 2016;5(1):55-61.

Williams, A. M., \& Suchdev, P. S. (2017). Assessing and improving childhood nutrition and growth globally. Pediatric Clinics of North America, 64(4), 755-768. doi: $\underline{10.1016 / j \cdot p c l .2017 .03 .001}$

Zanello, G., Srinivasan, C. S., \& Shankar, B. (2016). What explains Cambodia's success in reducing child stunting-2000-2014? PLoS One, 11(9), 1-22. doi: 10.1371/journal.pone.0162668 